\title{
$N$-FORMYL-MET-LEU-PHE-INDUCED OXIDATIVE BURST IN DMSO-DIFFERENTIATED HL-60 CELLS REQUIRES ACTIVE HSP90, BUT NOT INTACT MICROTUBULES
}

\author{
Jiří Vrba, Martin Modrianský* \\ Institute of Medical Chemistry and Biochemistry, Faculty of Medicine, Palacký University, Hnèvotínská 3, 77515 Olomouc, \\ Czech Republic
}

Received: September 9, 2004; Accepted: October 16, 2004

Key words: Radicicol/Hsp90/Microtubules/Oxidative burst/HL-60

In this study we examined whether microtubules and heat shock protein 90 (Hsp90) are involved in phorbol myristate acetate (PMA) and $N$-formyl-Met-Leu-Phe (fMLP)-induced oxidative burst in DMSO-differentiated HL-60 cells. Our results showed that microtubule interfering agents, paclitaxel (1-5 $\mu \mathrm{M})$, colchicine (1-100 $\mu \mathrm{M})$, nocodazole (1-20 $\mu \mathrm{M})$, and vincristine (1-50 $\mu \mathrm{M})$, did not affect either PMA or fMLP-induced oxidative burst. In contrast, radicicol, an inhibitor of Hsp90, inhibited fMLP-induced oxidative burst in time and concentration-dependent manner where $\mathrm{IC}_{50}$ value for $30 \mathrm{~min}$ pre-incubation was $16.5 \pm 3.5 \mu \mathrm{M}$ radicicol. We conclude that both PMA and fMLP-induced oxidative burst in DMSO-differentiated HL-60 cells is microtubule-independent while the latter requires Hsp90 activity.

\section{INTRODUCTION}

Superoxide radical generated during oxidative burst by phagocyte NADPH oxidase (EC 1.6.99.6) is a precursor of other reactive oxygen spe cies which are used for host defence against bacterial and fungal pathogens ${ }^{1}$. During the oxidase activation, cytosolic components of the oxidase (p67 ${ }^{\text {PHOX }}, \mathrm{p}^{4} 7^{\mathrm{PHOX}}, \mathrm{p} 40^{\mathrm{PHOX}}$, and small G-proteins Rac and Rap 1A) are induced to migrate to the cell membrane and form an active enzyme complex with membrane-bound flavocytochrome $\mathrm{b}_{558}$ consisting of gp91 ${ }^{\text {PHOX }}$ and $\mathrm{p} 22^{\text {PHOX }}$ $\left(\right.$ ref. $\left.^{2}\right)$. NADPH oxidase may be activated by various stimuli triggering the oxidative burst either via binding to receptor (e.g. Fc receptor, complement receptor or chemokine receptor) or by direct interaction with a component of a signalling cascade ${ }^{3}$. Although cytoskeleton plays a role in regulation of the NADPH oxidase assembly, the influence of the different states of the cytoskeletal proteins on the access of cytosolic components to flavocytochrome is unknown. In the resting cells, $\mathrm{p} 47^{\mathrm{PHOX}}$ and $\mathrm{p} 67^{\mathrm{PHOX}}$ are associated with the cytoskeleton, particularly with moesin, coronin and actin ${ }^{4}$, which was shown to interact also with recombinant Rac1 and Rac2. Furthermore, actin enhances activation, while actin depolymerizing agents facilitate deactivation of NADPH oxidase in cell-free system consisting of cytosol and plasma membrane ${ }^{5}$. Less is known about the possible role of microtubules in the oxidative burst. Reibman et al. ${ }^{6}$ showed that microtubule disruption in neutrophils treated with colchicine did not affect superoxide radical production stimulated via $\mathrm{Fc}$ receptors or receptors for $N$-formyl-Met-Leu-Phe (fMLP), thus the assembly of NADPH oxidase did not require intact microtubules. Treatment of neutrophils with vincristine, an inhibitor of microtubule assembly, did not impair myristate-induced superoxide release as well ${ }^{7}$. However, Wiles et al. ${ }^{8}$ demonstrated that colchicine attenuated and microtubule stabilization by paclitaxel increased fMLPinduced oxygen radical production by human neutrophils while experiments of Piazzolla et al. ${ }^{9}$ showed that paclitaxel inhibited fMLP-induced superoxide release by human neutrophils and colchicine had no effect.

The discrepancies in observed action of paclitaxel and colchicine inspired us to examine the effect of microtubule interfering agents, paclitaxel, colchicine, nocodazole, and vincristine, on fMLP and phorbol myristate acetate (PMA)-induced oxidative burst in DMSO-differentiated HL-60 cells. We included in our study also radicicol, an inhibitor of heat shock protein 90 (Hsp90) ${ }^{10}$, to investigate possible involvement of Hsp90 in signalling pathways leading to the oxidative burst, though radicicol was found to have no effect on fMLP-induced superoxide generation in primed or unprimed human neutrophils ${ }^{11}$.

\section{MATERIAL AND METHODS}

\section{Material}

Colchicine in $95 \%$ purity was isolated from corms of Colchicum autumnale at the Institute of Medical Chemistry and Biochemistry, Palacký University, Olomouc, Czech Republic. Paclitaxel semisynthetic from Taxus sp., nocodazole, vincristine sulfate, radicicol from Diheterospora chlamydosporia, phorbol 12-myristate 13acetate (PMA), $N$-formyl-Met-Leu-Phe (fMLP), diphenyleneiodonium chloride (DPI), superoxide dismutase from bovine erythrocytes (SOD), RPMI-1640 medium, L-glutamine, penicillin-streptomycin solution and fetal bovine serum were obtained from Sigma Chemical 
(Saint Louis, MO, USA). 2-methyl-6-(4-methoxyphenyl)3,7-dihydroimidazo[1,2-a]pyrazin-3-one hydrochloride (MCLA) was obtained from Molecular Probes (Eugene, OR, USA). All other chemicals were of the highest grade commercially available.

\section{HL-60 cell line maintenance and differentiation into neutrophils}

Human promyelocytic cell line HL-60 (ECACC No. 98070106) was maintained in RPMI-1640 medium containing $5 \mathrm{mM}$ L-glutamine, $100 \mathrm{U} / \mathrm{ml}$ penicillin, $0.17 \mathrm{mM}$ streptomycin, and $10 \%(\mathrm{v} / \mathrm{v})$ fetal bovine serum in a humidified incubator at $37^{\circ} \mathrm{C}$ and $5 \% \mathrm{CO}_{2}$. Cell density was maintained between 1 and $10 \times 10^{5}$ cells $/ \mathrm{ml}$. Prior to differentiation cells were collected by centrifugation for $3 \mathrm{~min}$ at $240 \mathrm{~g}$, resuspended in fresh medium and diluted to density $5 \times 10^{5}$ cells $/ \mathrm{ml}$. DMSO was added to reach $1.25 \%(\mathrm{v} / \mathrm{v})$ and the cells were cultured for 7 days in a humidified incubator at $37{ }^{\circ} \mathrm{C}$ and $5 \% \mathrm{CO}_{2}$. On day three fresh medium with DMSO was added to prevent cell starvation. Differentiated cells were collected by centrifugation as described above, washed once in PBS buffer (137 mM NaCl, $2.7 \mathrm{mM} \mathrm{KCl,} 9 \mathrm{mM} \mathrm{Na} \mathrm{HPO}_{4}, 1.5 \mathrm{mM}$ $\mathrm{KH}_{2} \mathrm{PO}_{4}, \mathrm{pH}$ 7.4), and finally resuspended in PBS supplemented with $0.5 \mathrm{mM} \mathrm{CaCl}_{2}, 1 \mathrm{mM} \mathrm{MgCl}$, and $30 \mathrm{mM}$ D-glucose (PBS+). Cells were then kept on ice and used for further experiments only when capable of superoxide generation, which was sensitive to inhibition by DPI and SOD.

\section{Chemiluminescent detection of superoxide formation}

Differentiated HL- 60 cells (final density $10^{6}$ cells $/ \mathrm{ml}$ ) were transferred into fluorescence quartz cuvette containing PBS+ buffer pre-warmed to $37^{\circ} \mathrm{C}$. DMSO (control) or a solution of tested substance in DMSO or DPI $(10 \mu \mathrm{M})$ or SOD $(100 \mathrm{U} / \mathrm{ml})$ were added 5,30 or $60 \mathrm{~min}$ prior to cell stimulation. MCLA $(4 \mu \mathrm{M})$ was added $30 \mathrm{~s}$ prior to start of measurement and the background chemiluminescence was obtained. Superoxide generation was initiated $60 \mathrm{~s}$ after the start of measurement by fMLP $(5 \mu \mathrm{M})$ or PMA $(0.1 \mu \mathrm{M})$. Maximum DMSO concentration in assay was $0.95 \%(\mathrm{v} / \mathrm{v})$.

The time course of MCLA-dependent chemiluminescence was monitored on Perkin Elmer LS50B luminometer (Perkin Elmer, Norwalk, CT, USA) equipped with total emission mirror and thermostatted cuvette holder allowing continuous stirring. The areas under chemiluminescence peak were integrated and used for calculation of half-maximal concentration $\left(\mathrm{IC}_{50}\right)$ necessary for inhibition of oxidative burst. Activity detected in samples containing $100 \mathrm{U} / \mathrm{ml}$ SOD was used as $100 \%$ inhibition.

\section{RESULTS AND DISCUSSION}

The DMSO-differentiated HL-60 cells respond to chemotactic peptide fMLP or phorbol ester PMA by triggering the superoxide radical generation. To explore the possible involvement of microtubules and Hsp90 in the oxidative burst, cells were pre-incubated with paclitaxel (1-5 $\mu \mathrm{M})$, colchicine $(1-100 \mu \mathrm{M})$, nocodazole $(1-20 \mu \mathrm{M})$, vincristine $(1-50 \mu \mathrm{M})$, and radicicol $(1-50 \mu \mathrm{M})$ for 5 or $30 \mathrm{~min}$ at $37^{\circ} \mathrm{C}$ and subsequently stimulated by fMLP or PMA. Tested microtubule interfering agents act by different mechanisms resulting in microtubule stabilization (paclitaxel) or microtubule disruption (colchicine, nocodazole, vincristine $)^{12}$, but none of these substances markedly af-

Table 1. Effect of paclitaxel, colchicine, nocodazole, vincristine, and radicicol on PMA and fMLP-induced oxidative burst in DMSO-differentiated HL-60 cells.

\begin{tabular}{|l|c|c|c|}
\hline Substance & $\begin{array}{c}\text { Concen- } \\
\text { tration } \\
(\mu \mathrm{M})\end{array}$ & $\begin{array}{c}\text { \% of control } \\
(\text { PMA) } \\
(\%)\end{array}$ & $\begin{array}{c}\% \text { of control } \\
(\text { fMLP) } \\
(\%)\end{array}$ \\
\hline Paclitaxel & 5 & $84.6 \pm 16.9$ & $96.4 \pm 9.8$ \\
\hline Colchicine & 100 & $96.3 \pm 0.4$ & $88.5 \pm 5.2$ \\
\hline Nocodazole & 20 & $123.1 \pm 0.2$ & $74.9 \pm 6.1^{\mathrm{a}}$ \\
\hline Vincristine & 50 & $104.7 \pm 7.3$ & $75.6 \pm 8.6^{\mathrm{a}}$ \\
\hline Radicicol & 50 & $64.0 \pm 6.0^{\mathrm{a}}$ & $11.8 \pm 5.1^{\mathrm{b}}$ \\
\hline
\end{tabular}

$10^{6}$ cells $/ \mathrm{ml}$ were pre-incubated for 30 min with DMSO (control) or tested substances prior to stimulation by PMA or fMLP. \% of control values show ratio of MCLAluminescence caused by cells treated with maximum applied concentration of tested substance and untreated cells. Values for radicicol were determined with differentiated HL- 60 cells of early passage. All data are means \pm SD from three experiments. ${ }^{a} \mathrm{p}<0.05,{ }^{\mathrm{b}} \mathrm{p}<0.005$ significantly different from control.

Table 2. Time-dependence of radicicol inhibition of fMLP-induced oxidative burst in DMSO-differentiated HL-60 cells.

\begin{tabular}{|c|c|c|}
\hline $\begin{array}{c}\text { Pre-incubation time } \\
(\mathrm{min})\end{array}$ & $\begin{array}{c}\text { IC50 } \\
(\mu \mathrm{M})\end{array}$ & $\begin{array}{c}\text { IC50* } \\
(\mu \mathrm{M})\end{array}$ \\
\hline 5 & $>100$ & 26.7 \\
\hline 30 & 16.5 & 6.0 \\
\hline 60 & 7.3 & Not done \\
\hline
\end{tabular}

$10^{6} \mathrm{cells} / \mathrm{ml}$ were pre-incubated for 5,30 or $60 \mathrm{~min}$ with DMSO (control) or different concentrations of radicicol prior to stimulation by fMLP. Dose-response curves were constructed and respective $\mathrm{IC}_{50} \mathrm{~s}$ were calculated. Data are means from at least two experiments. Values in column $\mathrm{IC}_{50}$ were determined with differentiated HL-60 cells of early passage, in column $\mathrm{IC}_{50}{ }^{*}$ with cells of later passage. 
fected either PMA or fMLP-induced oxidative burst in differentiated HL-60 cells (Table 1). While nocodazole appears to partially inhibit fMLP-induced oxidative burst, this inhibition may be attributed to non-specific effects due to substance precipitation which was noticeable even with the $20 \mu \mathrm{M}$ concentration of nocodazole. In contrast, radicicol, an inhibitor of Hsp90 (ref. ${ }^{10}$ ), inhibited fMLPinduced oxidative burst in time (Table 2) and concentration-dependent manner (Fig. 1). Cells of later passage, i.e. cells cultured for 6 or more weeks before differentiation, were more responsive to radicicol than cells differentiated 2 weeks after resuscitation (Table 2). In case of PMA stimulation we observed only partial inhibitory effect that required treatment of cells with $50 \mu \mathrm{M}$ radicicol for 30 min (Table 1). Moreover, radicicol at concentrations 1-50 $\mu \mathrm{M}$ did not inhibit sodium dodecyl sulfate-induced activation of NADPH oxidase in cell-free system containing cytosol and membranes obtained from unstimulated DMSO-differentiated HL-60 cells (data not shown).

Cell resistance towards microtubule interfering agents may result from $\beta$-tubulin gene mutations or multidrug resistance allowed by P-glycoprotein ${ }^{13}$. Because tested compounds bind to tubulin via different binding sites ${ }^{12}$ and neutrophils lack P-glycoprotein, which may eliminate colchicine $^{14}$, paclitaxel, and vincristine ${ }^{13}$, we conclude that both PMA and fMLP-induced oxidative burst in DMSOdifferentiated HL-60 cells is microtubule-independent. The requirement for Hsp90 function in fMLP-induced oxidative burst results probably from the triggering mechanisms where binding of fMLP to its G-protein-coupled receptors activates multiple signalling pathways while

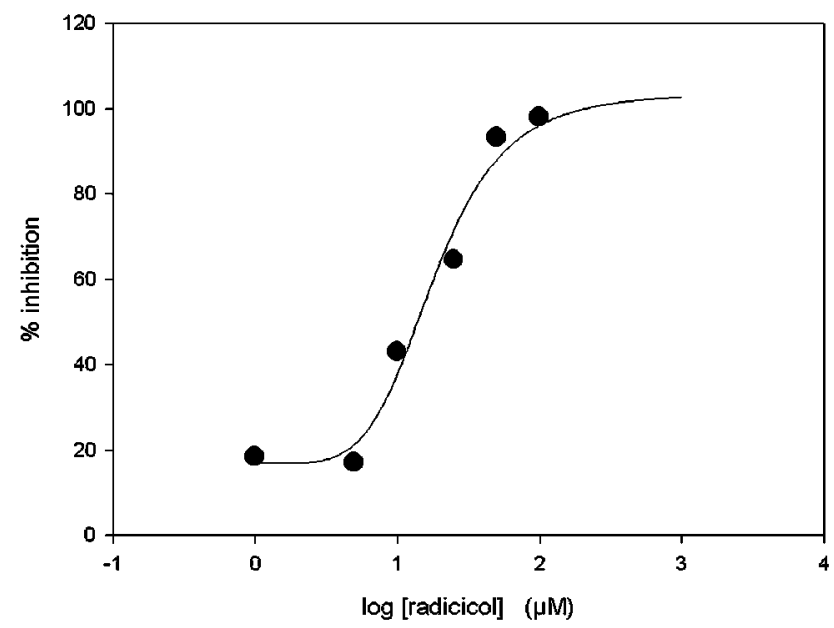

Fig. 1. Dose-response curve for radicicol inhibition of fMLP-induced oxidative burst in DMSO-differentiated HL-60 cells of early passage. $10^{6}$ cells $/ \mathrm{ml}$ were pre-incubated with different concentrations of radicicol for $30 \mathrm{~min}$ prior to stimulation by fMLP. Inhibition was calculated from chemiluminescent trace areas where $0 \%$ inhibition represents superoxide generation in the presence of fMLP alone and $100 \%$ inhibition in the presence of $100 \mathrm{U} / \mathrm{ml} \mathrm{SOD}$ and fMLP. The $\mathrm{IC}_{50}$ value derived from three experiments was $16.5 \pm 3.5 \mu \mathrm{M}$ radicicol.
PMA interacts directly with protein kinase $\mathrm{C}$ (PKC) activating NADPH oxidase ${ }^{15}$. We hypothesize that Hsp90 acts upstream of PKC and in agreement with experiments of Inanobe et al. ${ }^{16}$, which demonstrated that Hsp90 from HL-60 cells interacted with free $\beta \gamma$ subunits of heterotrimeric G-proteins, we suggest Hsp90 as a possible target for modulation of the oxidative burst.

\section{ACKNOWLEDGEMENTS}

The study was supported by the Ministry of Education, Youth and Sports, Czech Republic, grant MSMT 151100003.

\section{REFERENCES}

1. Babior BM. (2000) Phagocytes and oxidative stress. Am J Med 109, 33-44.

2. Vignais PV. (2002) The superoxide-generating NADPH oxidase: structural aspects and activation mechanism. Cell Mol Life Sci 59, 1428-59.

3. Remer KA, Brcic M, Jungi TW. (2003) Toll-like receptor-4 is involved in eliciting an LPS-induced oxidative burst in neutrophils. Immunol Lett 85, 75-80.

4. Cross AR, Segal AW. (2004) The NADPH oxidase of professional phagocytes - prototype of the NOX electron transport chain systems. Biochim Biophys Acta 1657, 1-22.

5. Tamura M, Kai T, Tsunawaki S, Lambeth JD, Kameda K. (2000) Direct interaction of actin with p47(phox) of neutrophil NADPH oxidase. Biochem Biophys Res Commun 276, 1186-90.

6. Reibman J, Haines KA, Gude D, Wissmann G. (1991) Differences in signal transduction between Fc gamma receptors (Fc gamma RII, Fc gamma RIII) and FMLP receptors in neutrophils. Effect of colchicine on pertussis toxin sensitivity and diacylglycerol formation. J Immunol 146, 988-96.

7. Katoh M, Fukuhara Y, Chiba T, Shirai T, Kitagawa S, Kakinuma K. (1991) Aclacinomycin, an anti-leukemic anthracycline, impairs human neutrophil fumctions. Int J Hematol 54, 49-55.

8. Wiles ME, Dykens JA, Wright CD. (1995) Human neutrophil (PMN) oxygen radical production and the cytoskeleton. Life Sci 57, 1533-46.

9. Piazzolla G, Tortorella C, Serrone M, Jirillo E, Antonaci S. (1998) Modulation of cytoskeleton assembly capacity and oxidative response in aged neutrophils. Immunopharmacol Immunotoxicol 20, 251-66.

10. Roe SM, Prodromou C, O’Brien R, Ladbury JE, Piper PW, Pearl LH. (1999) Structural basis for inhibition of the Hsp90 molecular chaperone by the antitumor antibiotics radicicol and geldanamycin. J Med Chem 42, 260-6.

11. Cadwallader KA, Condliffe AM, McGregor A, Walker TR, White JF, Stephens LR, Chilvers ER. (2002) Regulation of phosphatidylinositol 3-kinase activity and phosphatidylinositol 3,4,5-trisphosphate accumulation by neutrophil priming agents. J Immunol 169, 3336-44.

12. Jordan A, Hadfield JA, Lawrence NJ, McGown AT. (1998) Tubulin as a target for anticancer drugs: agents which interact with the mitotic spindle. Med Res Rev 18, 259-96.

13. Maeno K, Ito K, Hama Y, Shingu K, Kimura M, Sano M, Nakagomi H, Tsuchiya S, Fujimori M. (2003) Mutation of the class I beta-tubulin gene does not predict response to paclitaxel for breast cancer. Cancer Lett 198, 89-97.

14. Ben-Chetrit E, Levy M. (1998) Does the lack of the P-glycoprotein efflux pump in neutrophils explain the efficacy of colchicine in familial Mediterranean fever and other inflammatory disease? Med Hypotheses 51, 377-80. 
15. Kim C, Dinauer MC. (2001) Rac2 is an essential regulator of neutrophil nicotinamide adenine dinucleotide phosphate oxidase activation in response to specific signaling pathways. J Immunol $166,1223-32$.

16. Inanobe A, Takahashi K, Katada T. (1994) Association of the beta gamma subunits of trimeric GTP-binding proteins with $90-\mathrm{kDa}$ heat shock protein, hsp90. J Biochem (Tokyo) 115, 486-92. 